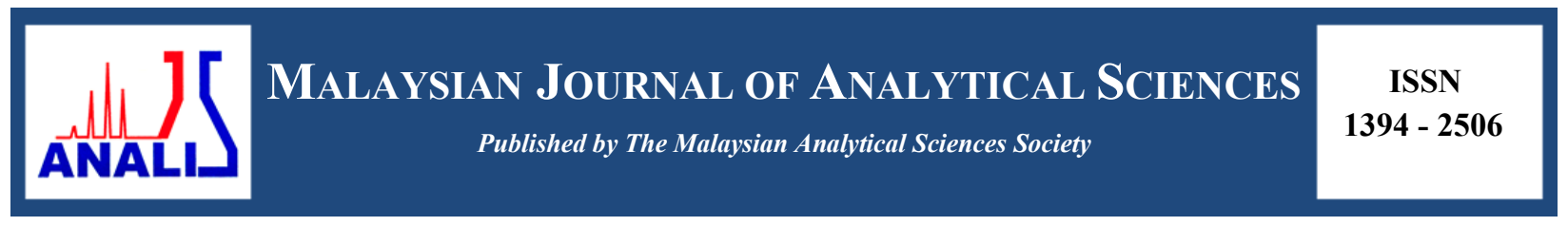

\title{
SYNTHESIS AND CHARACTERIZATION OF HYDROXYAPATITE FROM BULK SEASHELLS AND ITS POTENTIAL USAGE AS LEAD IONS ADSORBENT
}

\author{
(Sintesis dan Pencirian Hidroksiapatit dari Kulit Kerang dan Potensi Sebagai Penjerap \\ Ion Plumbum) \\ Marinah Mohd Ariffin ${ }^{1 *}$, Norhafiza Ilyana Yatim¹, Sofiah Hamzah² \\ ${ }^{I}$ School of Marine and Environmental Sciences \\ ${ }^{2}$ School of Ocean Engineering \\ Universiti Malaysia Terengganu, 21300 Kuala Terengganu, Malaysia \\ *Corresponding author: erin@umt.edu.my
}

Received: 16 August 2016; Accepted: 27 March 2017

\begin{abstract}
In the present work, hydroxyapatite (HAP) powder was successfully synthesized via the thermal decomposition and subsequent wet precipitation (with different experimental reaction times of 3, 5, 24, 48, and 72 hours of bulk seashells. We found that the reaction time during wet precipitation stage affected the physical and chemical properties of HAPs adsorbents. HAP synthesized with a reaction time of 48 hours showed the highest removal of $\mathrm{Pb}^{2+}$ ions $(99.1 \%)$ and is highly potential to be used as bio adsorbent material in heavy metal wastewater treatment.
\end{abstract}

Keywords: hydroxyapatite, seashell, wet precipitation, lead

\begin{abstract}
Abstrak
Di dalam kajian ini, serbuk hidroksiapatit (HAP) telah berjaya disintesis dari kulit kerang melalui proses penguraian termal dan diikuti oleh teknik pemendakan basah (dengan masa tindakbalas kajian 3, 5, 24 dan 72 jam). Kajian mendapati masa tindakbalas mempengaruhi ciri-ciri fizikal dan kimia penjerap HAP. HAP yang disintesis dengan masa tindakbalas selama 48 jam menunjukkan peratusan penyingkiran ion $\mathrm{Pb}^{2+}$ tertinggi $(99.1 \%$ ) dan berpotensi untuk digunakan sebagai bahan penjerap-bio bagi pemulihan logam berat di dalam air sisa.
\end{abstract}

Kata kunci: hidroksiapatit, kulit kerang, pemendakan basah, plumbum

\section{Introduction}

Water contamination often occurs due to anthropogenic activities such as manufacturing industries and agriculture. The untreated wastes from these activities are discharged directly into the environment, causing adverse impact on both the environment and human. Lead is one of the harmful pollutants which can cause irreversible neurological harms, e.g. kidney diseases, nervous disorders and reproductive toxicity [1]. The main factors contributing to lead contamination are from pipes, batteries, cable sheathing, and lead sheets [2]. The Ministry of Health Malaysia set the benchmark for both raw and drinking water quality index, with a maximum acceptable value of lead at 0.05 $\mathrm{mg} / \mathrm{L}$ and $0.01 \mathrm{mg} / \mathrm{L}$, respectively [3]. Various conventional methods have been introduced to remove heavy metals from wastewater, including chemical precipitation, membrane filtration, ion exchange, carbon adsorption, and coprecipitation/adsorption [4]. However, due to operational demerits, high cost of the treatment, the generation of 
toxic chemical sludge and incomplete removal of the pollutants, the conventional methods are least favourable [5]. Therefore, in search of alternatives, many researchers have applied regenerated natural wastes to produce an efficient and low cost treatment technology for heavy metal treatment.

Nowadays, studies using hydroxyapatite, $\mathrm{Ca}_{10}\left(\mathrm{PO}_{4}\right)_{6}(\mathrm{OH})_{2}$, (HAP) are being rapidly conducted and due to its versatility, it is applied in various fields such as biomedical application [6,7], bone tissue engineering [8,9], and wastewater treatment [10 - 12]. In addition, HAP has appealed a great deal of attention as a good adsorbent. It is highly stable under reducing and oxidizing conditions and possesses various favourable surface characteristics, such as surface functional groups, acidity and basicity, surface charge, hydrophilicity and porosity. The heavy metal sorption takes place through ionic exchange reaction, surface complexation with phosphate, calcium and hydroxyl groups and/or co-precipitation of new partially soluble phases [13].

HAP, also commonly known as calcium phosphate ceramic or bioceramic, exhibits similar structure and composition to the mineral phase of bones and teeth. Every year, 63,000 metric ton of shell fish wastes are generated worldwide and about $70 \%$ of this total weight is represented by clam shells. Easily available and abundant in nature, a renovation of these clam shell wastes into value-added HAP can be highly profitable [14]. HAP can also be produced from other natural calcium sources, e.g. corals, eggshell [15], cuttlefish shells, natural gypsums, bovine bones and seashells [16]. Various HAP production methods are developed: preparation methods such as hydrothermal method [17], microwave-assisted hydrothermal rapid synthesis [18], combustion method [19], precipitation, sol-gel technique, multiple emulsion, biomimetic deposition technique and electro deposition approach [20]; experimental conditions can also be modified according to the needs of applications prior to use. The type of source, method of preparation and different conditions will create HAP with different chemical and physical properties.

Therefore, in the present work, HAP was produced from marine waste via straightforward analysis technique by controlling the reaction time taken to produce high quality of HAP adsorbent in optimum condition. The changes of physical and chemical characteristics of the resulting HAP were discussed. The produced HAP is a potential leadremoval adsorbent, removing lead from contaminated water, thus curbing water pollution due to anthropogenic activities by converting wastes into valuable material.

\section{Materials and Methods}

\section{Instrument}

The purity of HAP adsorbents was examined by X-ray diffraction (XRD) using $\mathrm{Cu} \mathrm{K} \alpha$ radiation $(\lambda 1 / 41.5406 \AA$ ) on a SmartLab X-ray diffractometer (Rigaku). Fourier Transform infrared (FTIR) spectroscopy technique using potassium bromide $(\mathrm{KBr})$ pellet method was conducted using Perkin Elmer Spectrum 2000 FT-IR Spectrometer to define the information functional groups of HAP present in adsorbents. The adsorbent surface morphologies were studied using scanning electron microscope (SEM) (JEOL model JSM-6360 LA), and analysed using Brunauer, Emmett, and Teller (BET) analysis (Micromeritics, ASAP-2020). An Inductively Couple Plasma-Optical Emission Spectroscopy (ICP-OES) Shimadzu was used for $\mathrm{Pb}^{2+}$ analysis.

\section{Raw material and chemical}

Bulk seashells were randomly collected from Teluk Ketapang beach, Terengganu. Standard solution $(1000 \mathrm{mg} / \mathrm{L} \mathrm{of}$ lead) was prepared from lead (II) nitrate, $\mathrm{Pb}\left(\mathrm{NO}_{3}\right)_{2}$ (Merck, Germany) and used as stock solution of $\mathrm{Pb}(\mathrm{II})$. The working solutions of lower concentrations were prepared by dilutions series. All standard solutions were stored in refrigerator at $4{ }^{\circ} \mathrm{C}$. Ammonium hydrogen dibasic was supplied by Merck, Germany. Deionised water was purified by Purelab Ultra, ELGA with Millipore $18.2 \mu \Omega$. All reagents used were of analytical grade.

\section{Synthesis of hydroxyapatite}

Bulk seashells were cleaned and dried in oven at $60^{\circ} \mathrm{C}$ overnight. After crushed and pulverized, the seashell powder was calcined at $1000{ }^{\circ} \mathrm{C}$ for 1 hour in a furnace. HAP 3 was synthesized by slowly adding $150 \mathrm{~mL}$ of dissolved diammonium hydrogen phosphate solution to the $150 \mathrm{~mL}$ of calcined seashell powder with a $\mathrm{Ca} / \mathrm{P}$ ratio of 1.68 . The solution was then stirred at room temperature for 3 hours. The resulting precipitate was filtered using nylon cellulose filter paper (pore size $=0.25 \mu \mathrm{m}$ ) and extensively washed with deionized water to neutralize the 
precipitate. Subsequently, the HAP 3 was dried in oven at $100{ }^{\circ} \mathrm{C}$ overnight. Finally, the HAP 3 was sieved at a size range of less than $38 \mu \mathrm{m}$ before being stored in tight container for further analyses. This experimental procedure was repeated to produce HAP 5, HAP 24, HAP 48 and HAP 72 by changing the reaction time during stirring from 3 to 5, 24, 48 and 72 hours. The physical and chemical characterizations of the HAPs powders produced were examined. The chemical reaction involved in the experiment is stated as equation 1 and 2 below:

$$
\begin{aligned}
& \mathrm{CaCO}_{3} \stackrel{1000{ }^{\circ} \mathrm{C}}{\longrightarrow} \mathrm{CaO}+\mathrm{CO}_{2} \\
& 10 \mathrm{CaO}+6\left(\mathrm{NH}_{4}\right)_{2} \mathrm{HPO}_{4}+4 \mathrm{H}_{2} \mathrm{O} \longrightarrow \mathrm{Ca}_{10}\left(\mathrm{PO}_{4}\right)_{6}(\mathrm{OH})_{2}+12 \mathrm{NH}_{4} \mathrm{OH} \\
& \text { Hydroxyapatite }
\end{aligned}
$$

\section{Adsorption method}

Batch adsorption experiment was conducted to study the $\mathrm{Pb}^{2+}$ ions adsorption performance of different types of HAPs adsorbents. The experiments were conducted by mixing HAP adsorbent $(0.4 \mathrm{~g})$ in $200 \mathrm{~mL}$ of lead (II) nitrate solution $(25 \mathrm{mg} / \mathrm{mL})$ in a $250 \mathrm{~mL}$ Schott bottle. The solutions were equilibrated using controlled mechanical shaker at $150 \mathrm{rpm}$ in room temperature. The aliquot supernatant was collected at fix time intervals $(0,15,30,60,120,150$, 180, 210 and 240 minutes). The concentration changes of $\mathrm{Pb}^{2+}$ were determined using ICP-OES.

The percentage of lead removal $(\% \mathrm{R})$, quantity adsorbed by adsorbent $\left(\mathrm{q}_{\mathrm{t}}\right)$ and adsorption capacity of adsorbent $\left(\mathrm{q}_{\mathrm{e}}\right)$ were calculated using equation 3,4 and 5, respectively:

$$
\begin{aligned}
& \% \mathrm{R}=\left[\left(\mathrm{C}_{0}-\mathrm{C}_{\mathrm{e}}\right) / \mathrm{C}_{0}\right] \times 100 \% \\
& \mathrm{q}_{\mathrm{e}}=\left(\mathrm{C}_{0}-\mathrm{C}_{\mathrm{eq}}\right) \mathrm{V} /(\mathrm{M}) \\
& \mathrm{q}_{\mathrm{t}}=\left(\mathrm{C}_{0}-\mathrm{C}_{\mathrm{t}}\right) \mathrm{V} /(\mathrm{M})
\end{aligned}
$$

where, $\mathrm{C}_{0}, \mathrm{C}_{\mathrm{t}}$ and $\mathrm{C}_{\mathrm{eq}}$ are the initial, at time $\mathrm{t}(\mathrm{min})$ and equilibrium concentration of heavy metal ion in the solution $(\mathrm{mg} / \mathrm{L})$, respectively. The $\mathrm{q}_{\mathrm{e}}$ is the adsorption capacity in $(\mathrm{mg} / \mathrm{g}), \mathrm{q}_{\mathrm{t}}$ is the amount of lead adsorbed at time $(\mathrm{mg} / \mathrm{g}), \mathrm{V}$ is the total volume of the solution ( $\mathrm{L}$ ) and $\mathrm{M}$ is the amount of composite adsorbent (g).

\section{Kinetic and equilibrium modelling}

The effect of initial concentrations of adsorbate, $\mathrm{Pb}^{2+}(25,50,75,100,125,150$, and $200 \mathrm{mg} / \mathrm{L})$ was observed. In each batch experiment, $200 \mathrm{~mL}$ of aqueous metal ion solution of desired concentration was prepared and a fix weight of adsorbent, $0.4 \mathrm{~g}$ was added. The mixed solution was equilibrated with controlled mechanical shaker at $150 \mathrm{rpm}$. Supernatants were collected at various time intervals $(0,15,30,60,120,150,180,210$ and 240 minutes), and the concentration of lead was determined using ICP-OES analysis. All experiments were carried out in triplicates and the mean values were presented.

Study of kinetic models is important to define the mechanism involved in the adsorption process of adsorbate onto adsorbent in aqueous solution. The kinetic models by Lagergren's pseudo-first order and McKay and Ho's pseudosecond order models were used to the analysis data [5]. The linear equation of pseudo-first and pseudo-second are expressed in equation 6 and 7, correspondingly.

$$
\begin{aligned}
& \log \left(\mathrm{q}_{\mathrm{e}}-\mathrm{q}_{\mathrm{t}}\right)=\log \mathrm{q}_{\mathrm{e}}-\left(\mathrm{k}_{1} / 2.303\right) \mathrm{t} \\
& \mathrm{t} / \mathrm{q}_{\mathrm{t}}=1 / \mathrm{k}_{2} \mathrm{q}_{\mathrm{e}}^{2}+\mathrm{t} / \mathrm{q}_{\mathrm{e}}
\end{aligned}
$$

where $\mathrm{q}_{\mathrm{e}}$ is the amount of lead adsorbed by the absorbent at equilibrium at specific time $\mathrm{q}_{\mathrm{t}}(\mathrm{mg} / \mathrm{g}) . \mathrm{k}_{1}\left(\mathrm{~min}^{-1}\right)$ is the biosorption rate constant of pseudo-first-order sorption. The graph of pseudo-first order was plotted as $\log \left(\mathrm{q}_{\mathrm{e}}-\mathrm{q}_{\mathrm{t}}\right)$ versus $t$, and the linear graph for pseudo-second-order was plotted as $t / q t$ against $t$. The pseudo-second order model rate constant, $\mathrm{k}_{2}(\mathrm{~g} / \mathrm{mg} \mathrm{min})$ and $\mathrm{q}_{\mathrm{e}}$ was obtained from the intercept and slope of the linear graph plotted. From the equation 8 , the initial biosorption rate, $\mathrm{h}(\mathrm{mg} / \mathrm{g} \mathrm{min})$ was calculated from the value obtained using pseudo-secondorder as stated below: 


$$
\mathrm{h}(\mathrm{mg} / \mathrm{g} \min )=\mathrm{k}_{2} \mathrm{q}_{\mathrm{e}}^{2}
$$

The equilibrium adsorption isotherm is important in designing a biosorption system. The relationship between the adsorbent and adsorbate in equilibrium can be described from the type of adsorption isotherms data plotted. In this study, the lead adsorption of HAP 48 adsorbent was tested using Langmuir and Freundlich isotherm models. The Freundlich and Langmuir isotherm are represented in equation 9 and 10 as below:

$$
\begin{aligned}
& \log \mathrm{q}_{\mathrm{e}}=\log \mathrm{K}_{\mathrm{F}}+(1 / \mathrm{n}) \log \mathrm{C}_{\mathrm{e}} \\
& \mathrm{C}_{\mathrm{e}} / \mathrm{q}_{\mathrm{e}}=\left(1 / \mathrm{Q}_{0} \mathrm{~b}\right)+\left(\mathrm{C}_{\mathrm{e}} / \mathrm{Q}_{0}\right)
\end{aligned}
$$

where $\mathrm{q}_{\mathrm{e}}$ is the amount of adsorbate adsorbed at equilibrium $(\mathrm{mg} / \mathrm{g})$ and $\mathrm{C}_{\mathrm{e}}$ is the equilibrium solute concentration $(\mathrm{mg} / \mathrm{L})$. Value of $\mathrm{K}_{\mathrm{F}}$ and $1 / \mathrm{n}$ are Freundlich constants, that related to the adsorption capacity and adsorption intensity of the adsorbent which are can be directly obtained from the intercept and slope of the linear plot of $\log \mathrm{q}_{\mathrm{e}}$ against $\log C_{e}$. Value of $b$ is the Langmuir constant related to the energy of biosorption $(\mathrm{L} / \mathrm{mg}), \mathrm{q}_{\mathrm{m}}$ is the maximum sorption capacity corresponding to complete monolayer coverage $(\mathrm{mg} / \mathrm{g})$. These $\mathrm{b}$ and $\mathrm{Q}_{0}$ were obtained from the intercept and slope, respectively from the linear plot of $\mathrm{C}_{\mathrm{e}} / \mathrm{q}_{\mathrm{e}}$ over $\mathrm{C}_{\mathrm{e}}$.

The favourable nature of adsorption can be expressed in terms of dimensionless separation factor of equilibrium parameter, which is shown in equation 10 below [22].

$$
\mathrm{R}_{\mathrm{L}}=1 / 1+\mathrm{bC} \mathrm{C}_{0}
$$

\section{Physical characterizations}

\section{Results and Discussion}

Figure 1 depicts the diffractograms of different types of HAPs produced at different reaction times. The broad peaks indicate an amorphous structure. This result is consistent with previous study, in which non-calcined HAP produced broad peaks as a result of poor crystallinity structure [23]. The reflection patterns of HAP 3, HAP 24, HAP 48 and HAP 72 matched the XRD pattern of hydroxyapatite $\left[\mathrm{Ca}_{10}\left(\mathrm{PO}_{4}\right)_{6}(\mathrm{OH})_{2}\right]$ (JCPDS standard No. 74-565). HAP 5 powder showed the presence of calcite peak matching the XRD pattern of carbonate hydroxyapatite, syn $\left[\mathrm{Ca}_{10}\left(\mathrm{PO}_{4}\right)_{3}\left(\mathrm{CO}_{3}\right)_{3}(\mathrm{OH})_{2}\right]$ (JCPDS standard No. 19-272). The highest peak of HAP was at $31.9^{\circ}$ and the adsorbent of HAP 48(315) showed the highest intensity, indicating the high purity of HAP 48 compared to others adsorbents (i.e. HAP 24(313), HAP 72(295), HAP 3(286) and HAP 5(258)). The calcite peak of HAP 5 at $29.42^{\circ}$ is considered as an intermediate product in the conversion of seashell (calcium carbonate) to calcium oxide. The production of HAP increased with reaction time and conversion is completed with the disappearance of the diffraction line of calcite [24].

Figure 2 illustrates the FTIR spectra of different types of HAP. A broad peak at $1031-1033 \mathrm{~cm}^{-1}$ demonstrated the stretching modes of P-O bonds of phosphate group $\left(\mathrm{PO}_{4}{ }^{3-}\right)$ in the HAP structure. The peak at $602 \mathrm{~cm}^{-1}$ and $563 \mathrm{~cm}^{-1}$ were due to the bending modes of $\mathrm{P}-\mathrm{O}$ bonds in phosphate groups [25]. A broad peak at $3421-3441 \mathrm{~cm}^{-1}$ were assigned to the hydroxyl group (-OH) vibration [26]. A weak band of functional group of carbonate, $\mathrm{CO}_{3}{ }^{2-}$ exhibited in the region $1419-1455$ and $873-875 \mathrm{~cm}^{-1}$ corresponded to the B-type carbonate substitution of the $\mathrm{PO}_{4}$ groups in the HAP structure [27]. The lower intensity of the carbonate bands of HAP 72 and HAP 48 showed that they were purer compared to other HAPs. 


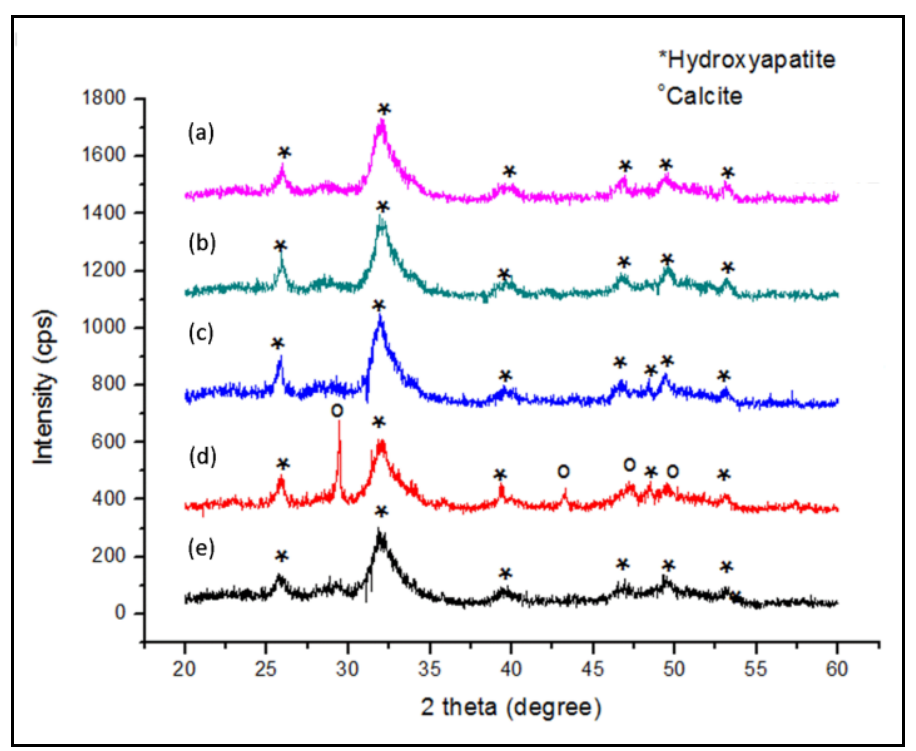

Figure 1. The XRD diffractogram of the HAP adsorbents. (a) HAP 72, (b) HAP 48, (c) HAP 24, (d) HAP 5 and (e) HAP 3

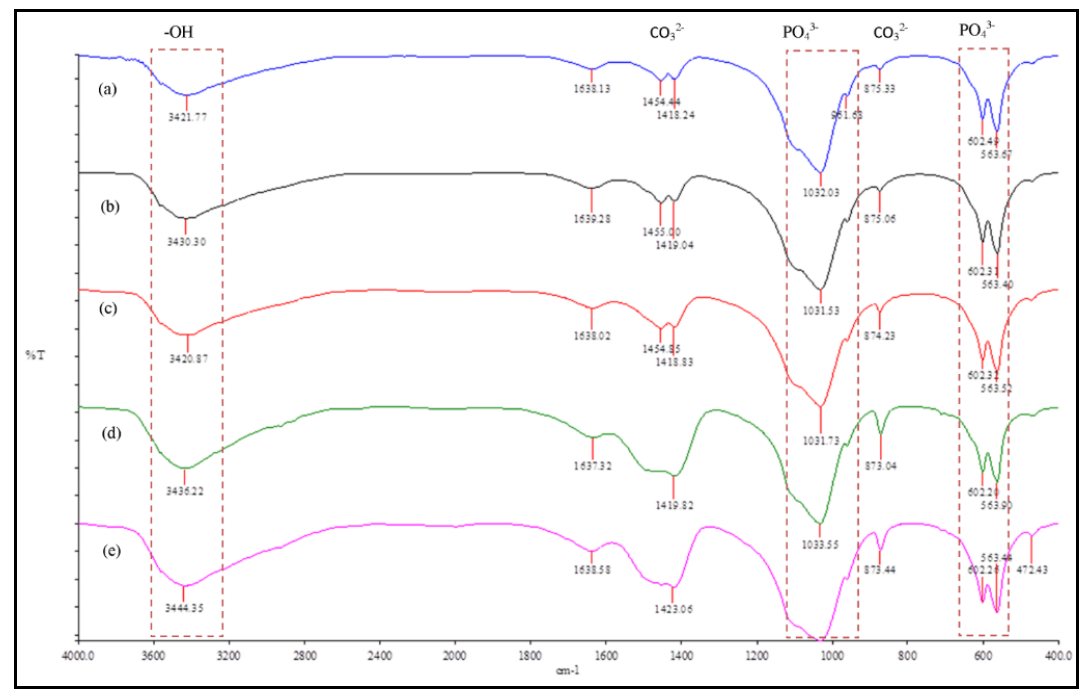

Figure 2. The FTIR spectra of HAP adsorbents. (a) HAP 72, (b) HAP 48, (c) HAP 24, (d) HAP 5 and (e) HAP 3

Based on these observations, the synthesis of HAP was successful based on the existence of the main functional groups of HAP, i.e. the hydroxyl group and phosphate group in each spectrum of HAP adsorbents. The reaction time exerted effects on the composition of the resulting HAP, which was clearly reflected from the band intensity of functional groups that appear in all spectra. A reaction time of 48 hours and 72 hours produced purer HAP structure, indicating that the reaction time is positively correlated with the conversion process of calcium carbonate, $\mathrm{CaCO}_{3}$ to hydroxyapatite, HAP molecule.

The surface and texture porosity of the HAPs were determined by nitrogen adsorption/desorption measurements at $77 \mathrm{~K}$ and the results of BET analysis are presented in Table 1. The data have shown that the reaction time was 
inversely proportional to the value of BET surface area. The HAP 3 exhibited the highest surface area, $126.51 \mathrm{~m}^{2} / \mathrm{g}$ while HAP 72 = gave the lowest value of BET surface area, $66.91 \mathrm{~m}^{2} / \mathrm{g}$. A possible explanation for this might be due to the agglomerate process that produced larger cluster of particles [28].

Table 1. The BET surface area, average pore volume and pore diameter of HAPs

\begin{tabular}{lccc}
\hline Type of Adsorbent & $\begin{array}{c}\text { BET Surface Area } \\
\left(\mathbf{m}^{2} / \mathbf{g}\right)\end{array}$ & $\begin{array}{c}\text { Average Pore Volume } \\
\left(\mathbf{c m}^{\mathbf{3}} \mathbf{g}\right)\end{array}$ & $\begin{array}{c}\text { Average Pore Diameter } \\
(\mathbf{n m})\end{array}$ \\
\hline HAP 3 & 126.6 & 0.482 & 13.05 \\
HAP 5 & 87.8 & 0.330 & 12.77 \\
HAP 24 & 76.6 & 0.438 & 20.53 \\
HAP 48 & 74.6 & 0.389 & 17.99 \\
HAP 72 & 66.9 & 0.347 & 17.12 \\
\hline
\end{tabular}

Figure 3 presents the isotherm graphs of HAPs produced at different reaction times. As shown in this figure, all the HAPs illustrated the physisorption isotherm type IV, indicating a mesoporous structure $(2-50 \mathrm{~nm}$ in diameter). This type of isotherm was determined based on the shape of hysteresis loop formed during capillary condensation process occurred in the mesoporous structures [29]. Based on Figure 3, the hysteresis loops of HAPs at relative pressure $\left(\mathrm{P} / \mathrm{P}_{0}\right)$ from 0.55 to 1.0 were of Type $\mathrm{H} 4$, thus indicating the presence of narrow-slit like pore pattern in the absorbents' structures.

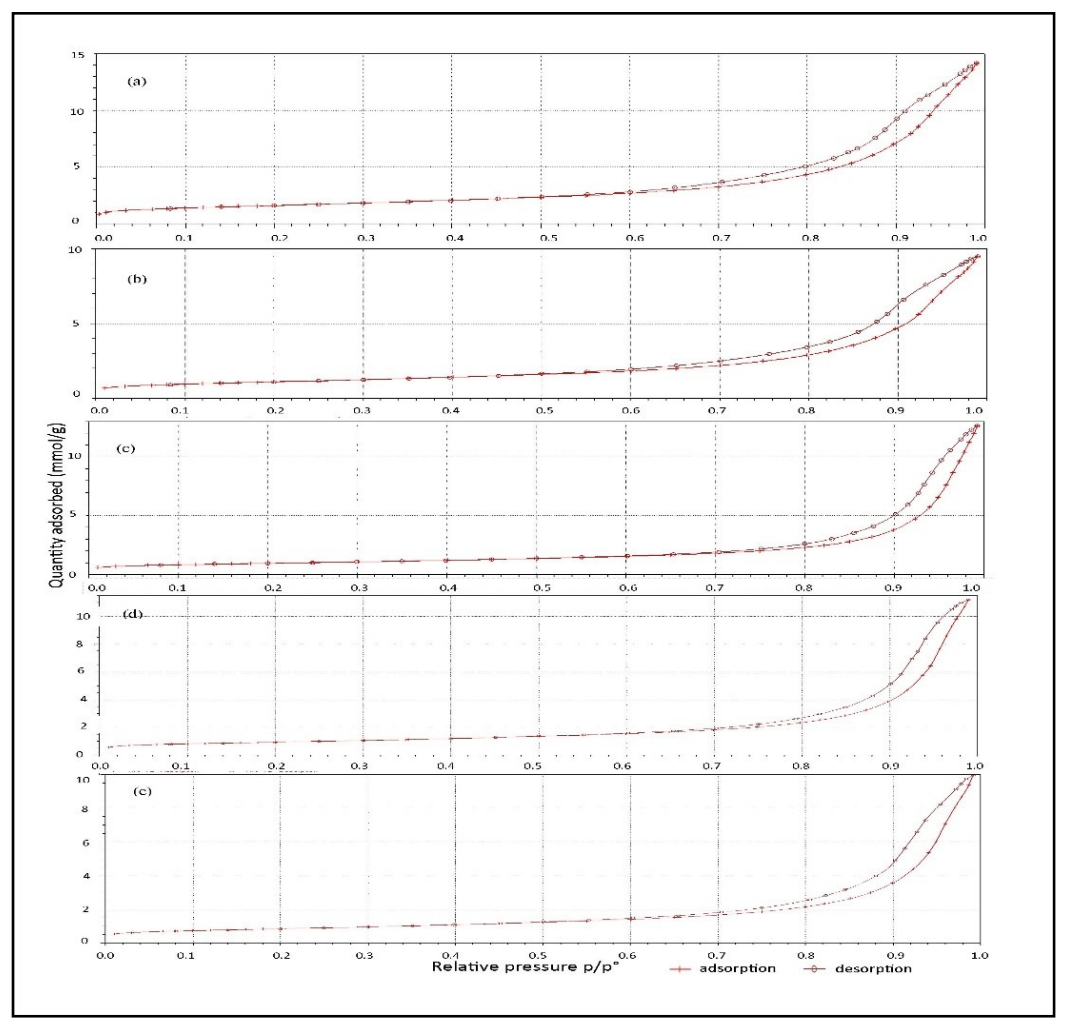

Figure 3. The nitrogen adsorption and desorption isotherm of HAP adsorbents. a) HAP 3, b) HAP 5, c) HAP 24, d) HAP 48 and e) HAP 72 
The HAP formation was governed by the nucleation and growth process. By increasing the reaction time, more spaces are available for HAP particles growth, thus producing more surface for the attachment of nucleate particles [30]. Figure 4 showed the typical SEM images of the prepared HAP adsorbents. All the synthesized HAPs showed irregular shapes and were accumulated in bulky sizes due to the uneven surface of HAP and the formation of platlike shape that overlapped each other. The morphology of HAP varies when using high temperature, carbonate sources, and the solvent extraction [31].
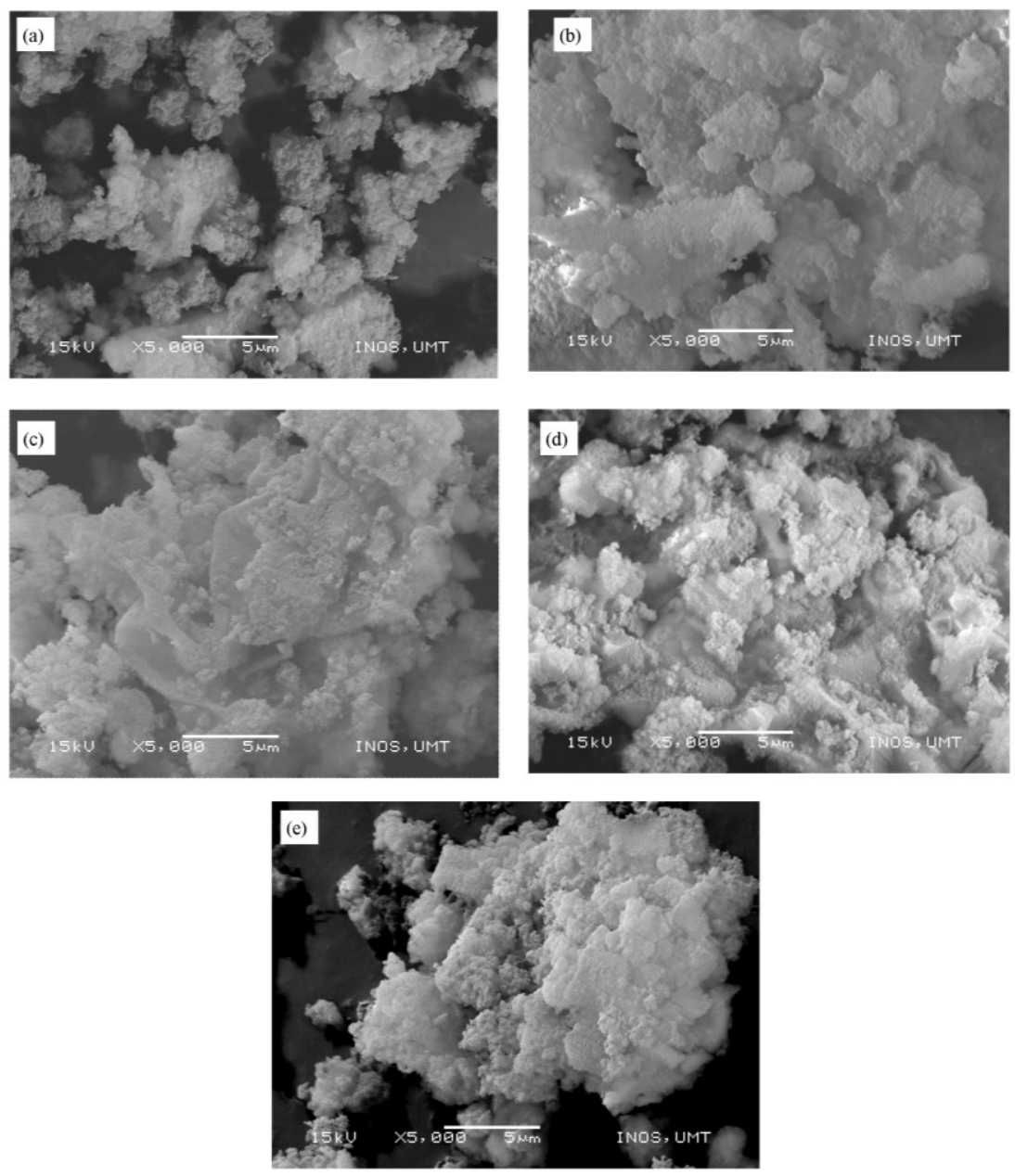

Figure 4. The scanning electron microscope (SEM) micrograph image of HAPs adsorbent at 5,000x magnifications. a) HAP 3,b) HAP 5, c) HAP 24, d) HAP 48 and e) HAP 72

\section{Selection of optimum HAP adsorbent}

The removal of lead $\left(\mathrm{Pb}^{2+}\right)$ by synthesized HAP adsorbents showed similar trends due to the similarities in their main chemical compositions (Figure 5). The selection of optimum adsorbent was based on the slope of the graph during the first 50 minutes of contact time, with HAP48 showing the steepest of slope followed by HAP72 > HAP3 $>$ HAP24 > HAP5. 


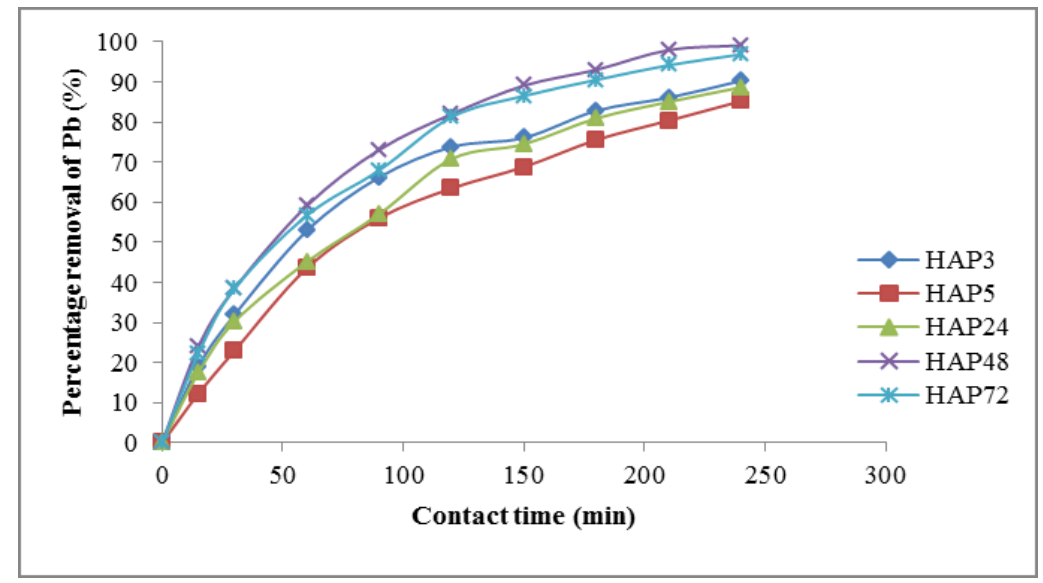

Figure 5. Removal of lead $\left(\mathrm{Pb}^{2+}\right)(\%)$ by prepared HAP adsorbents. (adsorbent dose: $0.4 \mathrm{~g}$; initial concentration and volume of $\left.\mathrm{Pb}^{2+}: 25 \mathrm{mg} / \mathrm{L}, 200 \mathrm{~mL}\right)$

The capability of HAP48 to absorb metal $\left(\mathrm{Pb}^{2+}\right)$ was the highest $(12.28 \mathrm{mg} / \mathrm{g})$, followed by HAP72 $(11.62 \mathrm{mg} / \mathrm{g})$, HAP3 $(11.6 \mathrm{mg} / \mathrm{g})$, HAP24 $(10.28 \mathrm{mg} / \mathrm{g})$ and HAP5 $(10.4 \mathrm{mg} / \mathrm{g})$. This result is similar to the XRD diffractogram (Figure 1), demonstrating the purity of HAP48 compared to the other adsorbents. It is clear that the time of reaction affected the chemical properties of HAP adsorbent by influencing the availability of active sites to adsorb the metal ions. Consequently, HAP48 adsorbent was determined as the optimum adsorbent for subsequent studies. HAP derived from seashells are used in wastewater treatment as fluoride removal [32], sulfur removal [33], and dye removal [34]. The HAP produced from similar source is also applied in other fields such as fluorescence-quenching platform for cancer cell detection [35], bone tissue engineering [36], and body implant application [37].

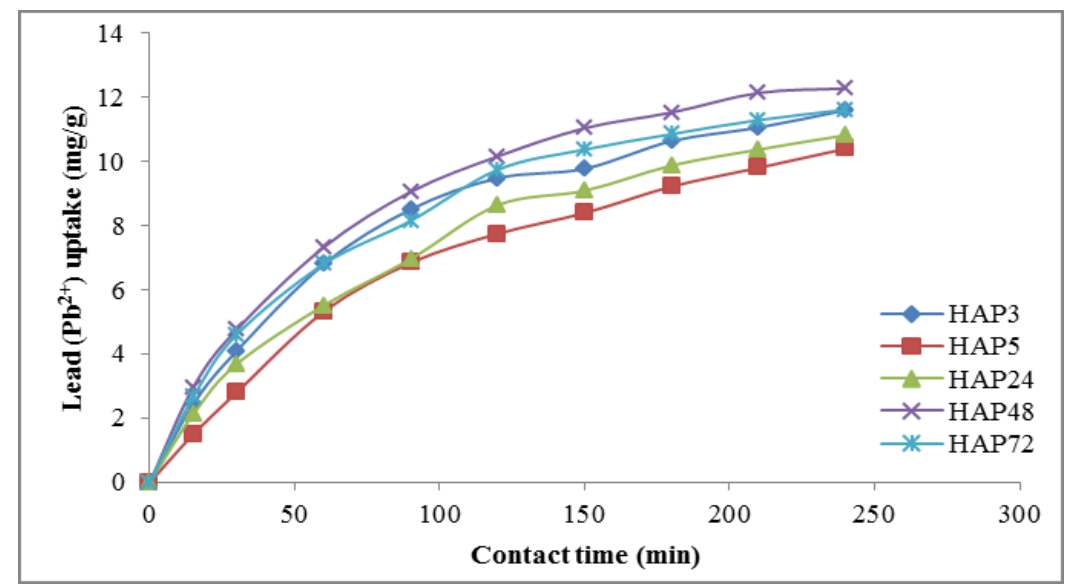

Figure 6. Effect of contact time on metal uptake $\left(\mathrm{Pb}^{2+}\right)$ by HAP adsorbents. (adsorbent dose: $0.4 \mathrm{~g}$; initial concentration and volume of $\mathrm{Pb}^{2+}: 25 \mathrm{mg} / \mathrm{L}, 200 \mathrm{~mL}$ )

\section{Effect of initial metal ions concentration and contact time}

Metal adsorption by the absorbent is influenced by the initial concentration of $\mathrm{Pb}^{2+}$ ion. Form the Figure 7, the adsorption of lead has occurred rapidly in the first $30 \mathrm{~min}$ and can be seen from the steep of slope at 0 to 30 minutes of contact time and subsequently, the system achieved equilibrium point after 90 minutes. This situation was due to the reduced availability of binding sites and the external sites were occupied [38]. 


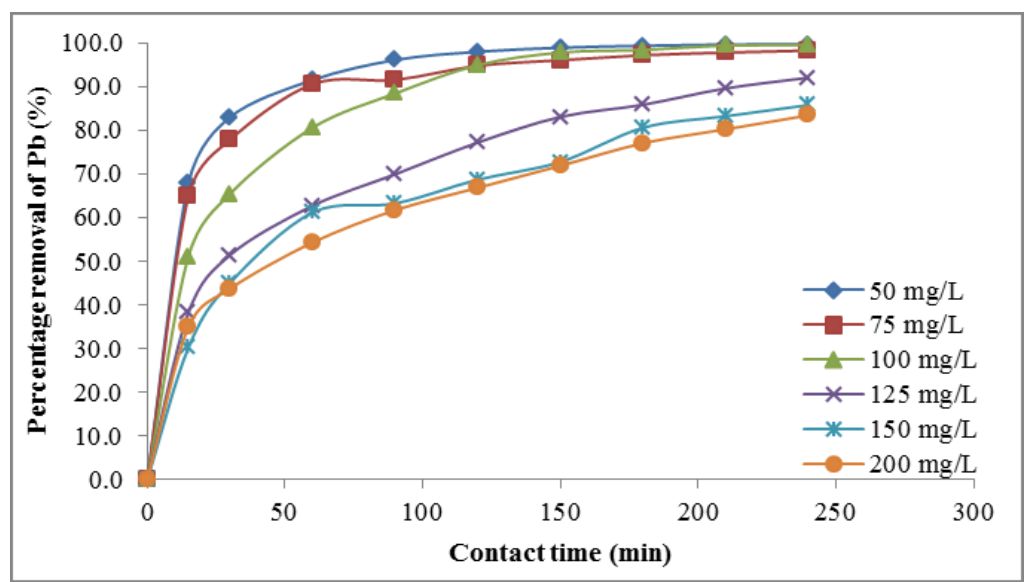

Figure 7. Effect of initial concentration of $\mathrm{Pb}$ on the percentage removal of $\left(\mathrm{Pb}^{2+}\right)(\mathrm{mg} / \mathrm{g})$ by HAP48 adsorbent. (adsorbent dose: $0.4 \mathrm{~g}$; volume of $\mathrm{Pb}^{2+}: 200 \mathrm{~mL}$ )

From Figure 8, the lowest initial concentration of $\mathrm{Pb}^{2+}(50 \mathrm{mg} / \mathrm{mL})$ achieved equilibrium in the shortest time compared to other higher initial concentrations in terms of the quantity of metal adsorbed $\left(\mathrm{Pb}^{2+}\right)$. During low initial concentration, metal ions are adsorbed by HAP on specific active sites. As the initial concentration of metal increases, so was the adsorption rate. The lowest initial concentration of $\mathrm{Pb}^{2+}$ achieved equilibrium fastest is due to the static weight of adsorbent [39].

The maximum uptake of $\mathrm{Pb}^{2+}$ by HAP48 achieved equilibrium at 60 minutes of contact time for initial concentration of $50 \mathrm{mg} / \mathrm{L}(20.87 \mathrm{mg} / \mathrm{g})$ and $75 \mathrm{mg} / \mathrm{L}(31.18 \mathrm{mg} / \mathrm{g})$. However, higher initial concentration required longer contact time to achieve equilibrium, 120 minutes for concentration $100 \mathrm{mg} / \mathrm{L}, 150$ minutes for $125 \mathrm{mg} / \mathrm{L}, 180$ minutes for 150 and $200 \mathrm{mg} / \mathrm{L}$ with the increased of adsorption capacity, $43.94 \mathrm{mg} / \mathrm{g}, 49.09 \mathrm{mg} / \mathrm{g}, 58.31 \mathrm{mg} / \mathrm{g}$, and $73.77 \mathrm{mg} / \mathrm{g}$, respectively. This similar pattern was also reported from previous study on methylene blue adsorption using activated carbon discovered from pineapple leaf [22].

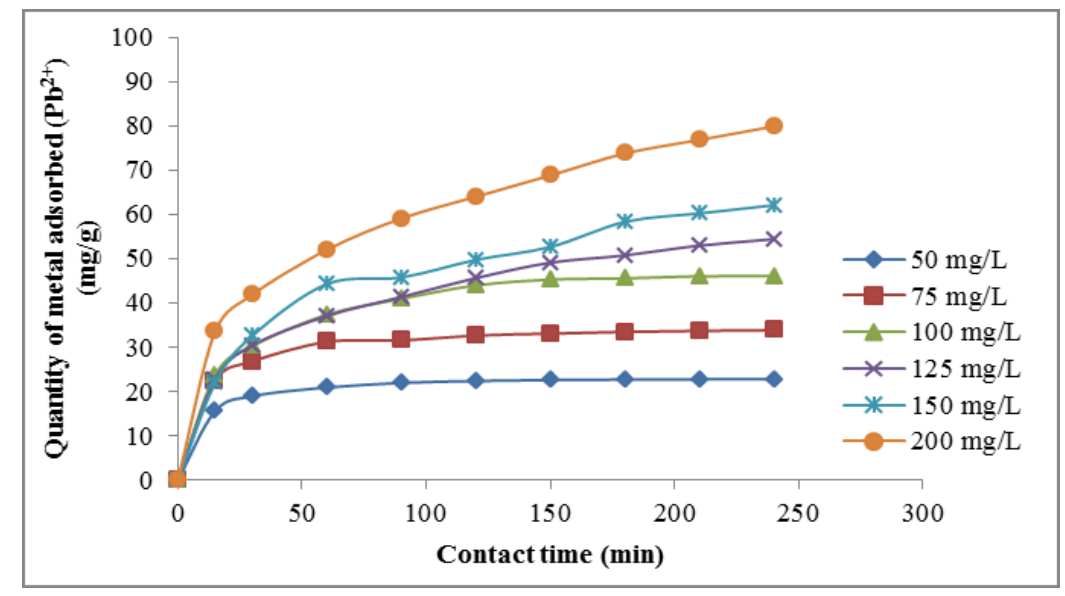

Figure 8. Effect of initial concentration of $\mathrm{Pb}$ on the quantity of metal adsorbed $\left(\mathrm{Pb}^{2+}\right)(\mathrm{mg} / \mathrm{g})$ by HAP48 adsorbent. (adsorbent dose: $0.4 \mathrm{~g}$; volume of $\mathrm{Pb}^{2+}: 200 \mathrm{~mL}$ ) 


\section{Kinetic adsorption study}

The adsorption experiment data of lead was fitted to pseudo-first-order and second-order as shown in Figure 9. The value of $\mathrm{R}^{2}$ of linear equation approaches value 1 designates that the respective equation corresponds well to the experimental data [22]. Therefore, the kinetic adsorption was fitted well to the pseudo-second-order model, with $\mathrm{R}^{2}$ value of 0.9994 for the bio adsorption system. This model, based on the chemisorption mechanism for metal ions interaction with adsorbent surface, was suggested as the rate-limiting step in HAP48 adsorbent [40]. This mechanism also described the physicochemical interactions between the two phases [41].
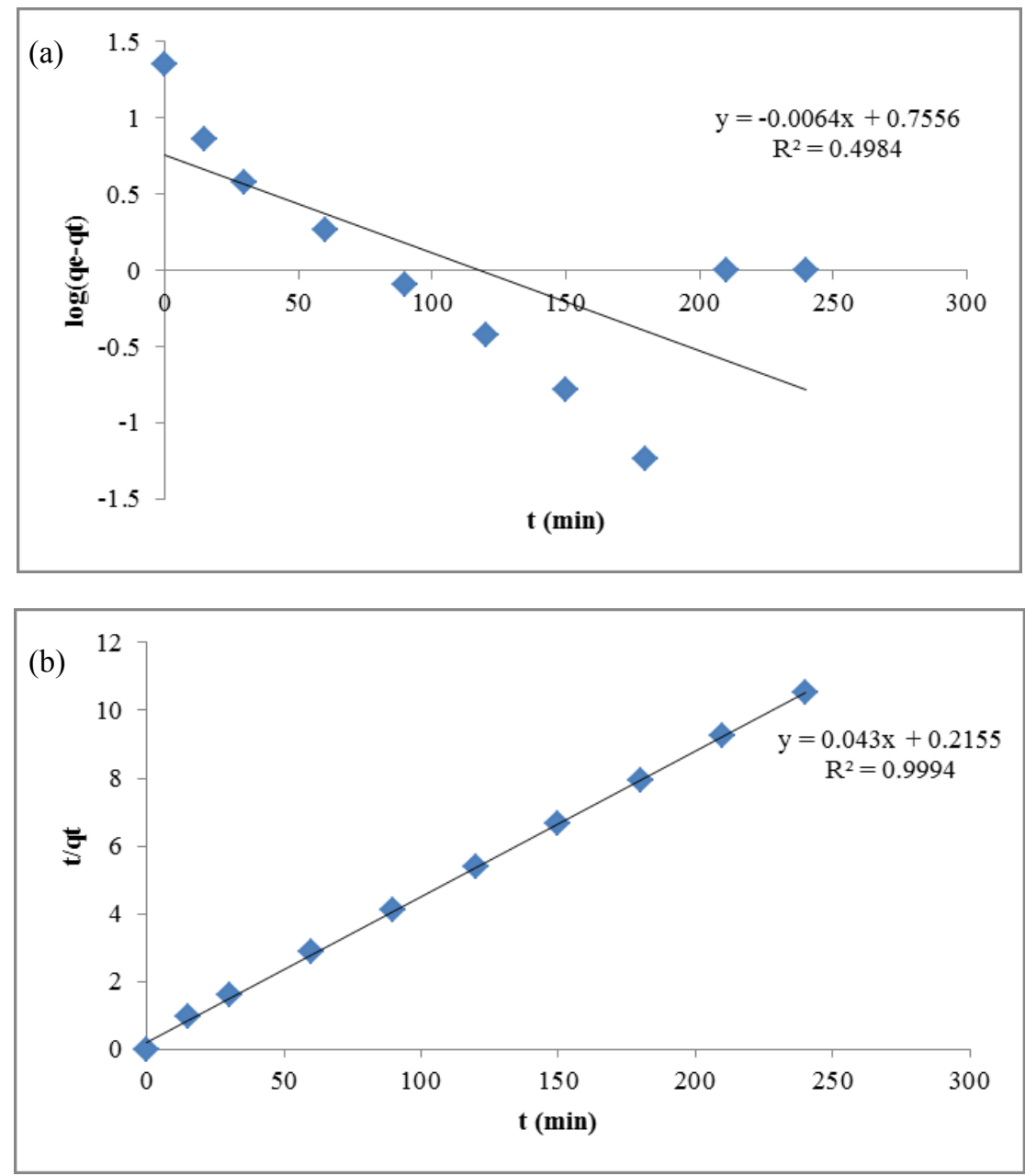

Figure 9. Pseudo-first-order (a) and pseudo-second-order (b) for kinetics model of ${ }^{\mathrm{Pb} 2+}$ adsorption onto HAP48

Initial concentration was inversely proportional to the adsorption rate, $\mathrm{k}_{2}$ and displayed in Table 2. Even increasing of initial concentration was decreasing the rate constant, $\mathrm{k}_{2}$, the adsorption capacity, $\mathrm{q}_{\mathrm{e}}$ was showed increasing trend. Similar pattern to the work on lead removal using modified coconut shells [42].

\section{Equilibrium adsorption study}

The linear plots for both isotherms are shown in Figure 10. It clearly presented that the adsorption data were well fitted with Langmuir isotherm, with $\mathrm{R}^{2}=0.973$ compared to Freundlich isotherm $\left(\mathrm{R}^{2}=0.865\right)$. The Langmuir model describes the formation of a monolayer adsorbate on the outer surface of the adsorbent, and no more adsorption 
takes place once a saturation value is reached [43]. The $\mathrm{R}_{\mathrm{L}}$ value of 0.013 (Table 3) indicates that the adsorption of $\mathrm{Pb}^{2+}$ onto HAP48 was favourable $\left(0<\mathrm{R}_{\mathrm{L}}<1\right)$ and had strong interaction with each other.

Table 2. The pseudo-second-order kinetic parameters for lead removal by HAP48 adsorbent

\begin{tabular}{ccccc}
\hline $\mathbf{C}_{\mathbf{0}(\mathbf{m g} / \mathbf{L})}$ & $\mathbf{q}_{\mathbf{e}(\mathbf{m g} / \mathbf{g})}$ & $\mathbf{k}_{\mathbf{2}}(\mathbf{g} / \mathbf{m g} \mathbf{m i n})$ & $\mathbf{h}(\mathbf{m g} / \mathbf{g} \mathbf{~ m i n})$ & $\mathbf{R}^{\mathbf{2}}$ \\
\hline 50 & 23.26 & 0.0086 & 4.640 & 0.999 \\
75 & 34.48 & 0.0047 & 5.593 & 0.999 \\
100 & 48.54 & 0.0016 & 3.837 & 0.996 \\
125 & 57.47 & 0.0008 & 2.493 & 0.984 \\
150 & 65.79 & 0.0006 & 2.488 & 0.978 \\
200 & 84.03 & 0.0005 & 3.285 & 0.978 \\
\hline
\end{tabular}
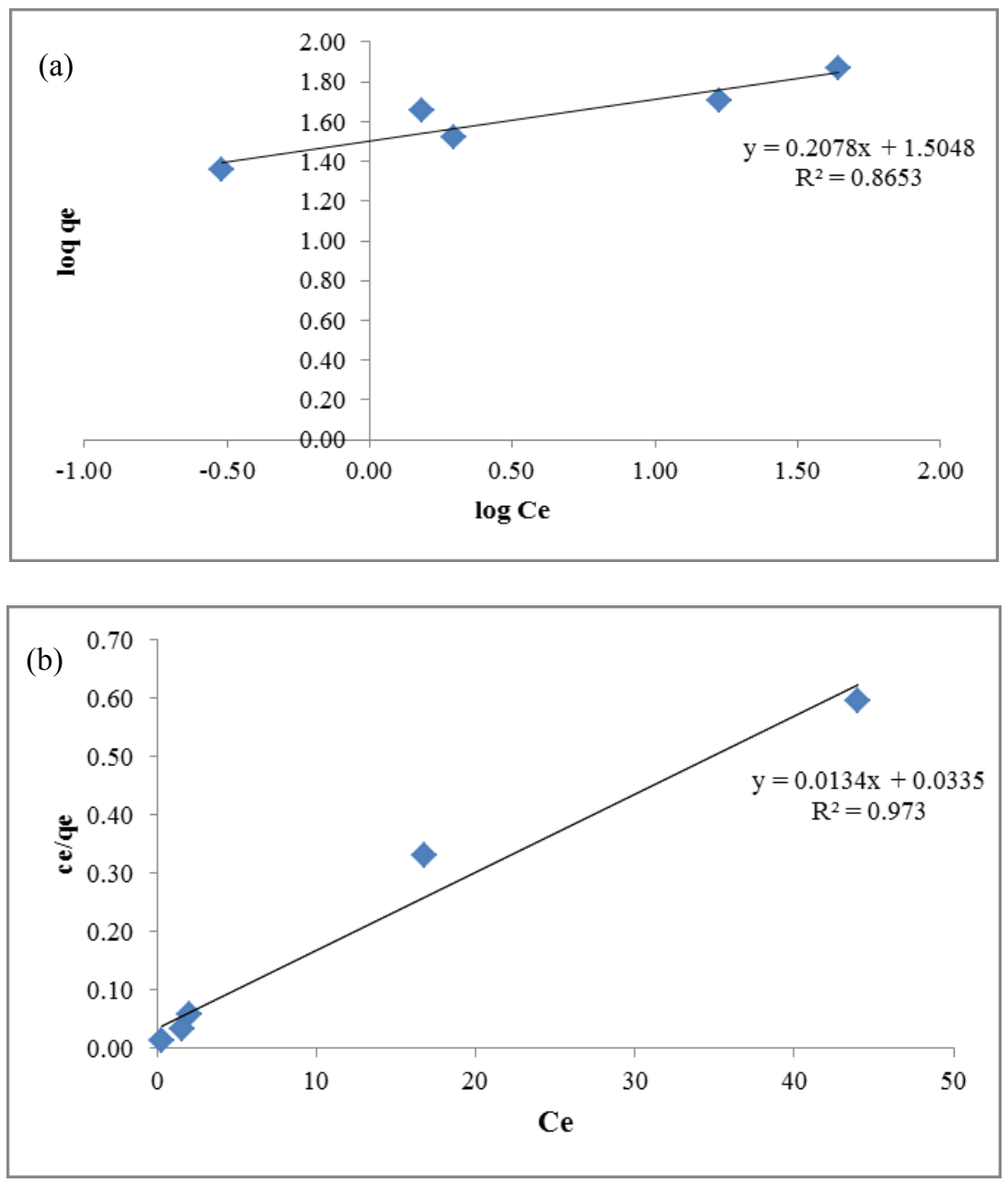

Figure 10. Freundlich (a) and Langmuir (b) adsorption isotherm models of $\mathrm{Pb}^{2+}$ adsorption onto HAP 48 


\section{Marinah et al: SYNTHESIS AND CHARACTERIZATION OF HYDROXYAPATITE FROM BULK SEASHELLS AND ITS POTENTIAL USAGE AS LEAD IONS ADSORBENT}

Table 3. Freundlich and Langmuir isotherms constants of lead $\left(\mathrm{Pb}^{2+}\right)$ biosorption onto HAP 48 adsorbent

\begin{tabular}{ccccccc}
\hline \multicolumn{3}{c}{ Freundlich Constants } & \multicolumn{4}{c}{ Langmuir Constants } \\
\hline $\mathbf{K}_{\mathbf{F}}$ & $\mathbf{n}$ & $\mathbf{R}^{2}$ & $\mathbf{q}_{\mathbf{m}}(\mathbf{m g} / \mathbf{g})$ & $\mathbf{b}(\mathbf{L} / \mathbf{m g})$ & $\mathbf{R}^{2}$ & $\mathbf{R}_{\mathbf{L}}$ \\
\hline 31.97 & 4.812 & 0.8653 & 74.63 & 0.4 & 0.973 & 0.013 \\
\hline
\end{tabular}

The maximum sorption capacity, $\mathrm{q}_{\mathrm{m}}$ of HAP48 was $74.63 \mathrm{mg} / \mathrm{g}$. Using dead calcareous skeletons (CS) as calcium carbonate source, maximum adsorption capacities of 26.5 and $38.5 \mathrm{mg} / \mathrm{g}$ for the $\mathrm{Cd}(\mathrm{II})$ and $\mathrm{Pb}(\mathrm{II})$ column, respectively were achievable [44]. However, Anadara inaequivalvis seashells powder had higher biosorption capacity of $\mathrm{Cu}(\mathrm{II})$ and $\mathrm{Pb}(\mathrm{II})(330.2$ and $621.1 \mathrm{mg} / \mathrm{g}$, respectively) [38]. The obtained result was postulate to be affected by the orthorhombic crystal structure of aragonite and the condition of the experiment conducted.

The interaction mechanism between $\mathrm{Pb}^{2+}$ ions and HAP48 adsorbent was determined via dissolution and precipitation process. The chemisorption interaction had occurred via the formation of new chemical bonding between adsorbate and adsorbent surface and was explained in the chemical reactions below [45]:

$$
\begin{aligned}
& \mathrm{Ca}_{10}\left(\mathrm{PO}_{4}\right)_{6}(\mathrm{OH})_{2}+14 \mathrm{H}_{2}^{+} \rightarrow 10 \mathrm{Ca}^{2+}+6 \mathrm{H}_{2} \mathrm{PO}_{4}^{-}+2 \mathrm{H}_{2} \mathrm{O} \text { (Dissolution process) } \\
& 10 \mathrm{~Pb}^{2+}+6 \mathrm{H}_{2} \mathrm{PO}_{4}^{-}+2 \mathrm{H}_{2} \mathrm{O} \rightarrow 14 \mathrm{H}_{2}^{+}+\mathrm{Pb}_{10}\left(\mathrm{PO}_{4}\right)_{6}(\mathrm{OH})_{2} \text { (Precipitation process) }
\end{aligned}
$$

\section{Conclusion}

In this study, a worthwhile bio adsorbent from marine bio-waste, HAP48 bio-adsorbent was successfully synthesized with optimal characteristics for the application of the removal of lead from contaminated water. Though the resulting HAP resembles that found naturally in terms of its composition, this continuous research efforts have produced new economic synthesis approaches and can be applied in future research. For subsequent study, the produced HAP will be combined with other potential adsorbents, as well as its absorbent ability in other multi-metal ions, adsorbent reusability and its production on pilot scale.

\section{Acknowledgement}

The authors would like to Thank and gratitude to Universiti Malaysia Terengganu for providing the facilities to conduct this research.

\section{References}

1. Sutherland, A. M. C. A., Milner, E. F., Kerby, R. C. and Teindl, H. (1990). Lead. Ullmann's Encyclopedia of Industrial Chemistry. VCH Verlagsgesellschaft: pp. $193-257$.

2. Das, S., Raj, R., Mangwani, N., Dash, H. R. and Chakraborty, J. (2014). Heavy metals and hydrocarbons: Adverse effects and mechanism of toxicity. Microbial Biodegradation and Bioremediation. Elsevier Inc: pp 24 -54 .

3. Engineering Services Division (2017). Drinking water quality standard. Acess online http://kmam.moh.gov.my/ public-user/drinking-water-quality-standard.html. Accessed on 12 January 2017.

4. Bailey, S. E., Olin, T. J., Bricka, R. M. and Adrian, D. D. (1999). A review of potentially low-cost sorbents for heavy metals. Water Research, 33(11): $2469-2479$.

5. Mudhoo, A., Garg, V. K. and Wang, S. (2011). Removal of heavy metals by biosorption. Environmental Chemistry Letters, 10(2): 109 - 117.

6. Shepherd, J. H., Friederichs, R. J. and Best, S. M. (2015). Synthetic hydroxyapatite for tissue engineering applications. Hydroxyapatite (HAP) for biomedical applications. Elsevier Ltd: pp. 235 - 267.

7. Camaioni, A., Cacciotti, I., Campagnolo, L. and Bianco, A. (2015). Silicon-substituted hydroxyapatite for biomedical applications. Hydroxyapatite (HAP) for biomedical applications. Elsevier Ltd: pp. 343 - 373. 
8. Milovac, D., Gallego, G., Ivankovic, M. and Ivankovic, H. (2014). PCL-coated hydroxyapatite scaffold derived from cuttle fish bone: Morphology, mechanical properties and bioactivity. Materials Science \& Engineering C, 34: $437-445$.

9. Zhang, X. and Vecchio, K. S. (2006). Creation of dense hydroxyapatite (synthetic bone) by hydrothermal conversion of seashells. Materials Science \& Engineering C, 26(8): 1445 - 1450.

10. Corami, A., Mignardi, S. and Ferrini, V. (2007). Copper and zinc decontamination from single- and binarymetal solutions using hydroxyapatite. Journal of Hazourdous Materials, 146(1-2): 164 - 170.

11. Minh, D. P., Tran, N. D., Nzihou, A. and Sharrock, P. (2013). Hydroxyapatite gel for the improved removal of $\mathrm{Pb}^{2+}$ ions from aqueous solution. Chemical Engineering Journal, 232: 128 - 138.

12. Prabhu, S. M., and Meenakshi, S. (2014). Synthesis of surface coated hydroxyapatite powders for fluoride removal from aqueous solution. Powder Technology, 268: 306 - 315 .

13. Mobasherpour, I., Salahi, E. and Pazouki, M. (2012). Comparative of the removal of $\mathrm{Pb}^{2+}, \mathrm{Cd}^{2+}$ and $\mathrm{Ni}^{2+}$ by nano crystallite hydroxyapatite from aqueous solutions: Adsorption isotherm study. Arabian Journal Chemistry, 5(4): 439 - 446.

14. Bramhe, S., Kim, T. N., Balakrishnan, A. and Chu, M. C. (2014). Conversion from biowaste Venerupis clam shells to hydroxyapatite nanowires. Materials Letters, 135: 195 - 198.

15. Wu, S.-C., Tsou, H.-K., Hsu, H.-C., Hsu, S.-K., Liou, S.-P. and Ho, W.-F. (2013). A hydrothermal synthesis of eggshell and fruit waste extract to produce nanosized hydroxyapatite. Ceramics International, 39(7): 8183 8188.

16. Sanosh, K. P., Chu, M.-C., Balakrishnan, A., Kim, T. N. and Cho, S.-J. (2009). Utilization of biowaste eggshells to synthesize nanocrystalline hydroxyapatite powders. Materials Letters, 63(24-25): 2100 -2102.

17. Aminian, A., Solati-Hashjin, M., Samadikuchaksaraei, A., Bakhshi, F., Gorjipour, F., Farzadi, A., Moztarzadeh, F. and Schmücker, M. (2011). Synthesis of silicon-substituted hydroxyapatite by a hydrothermal method with two different phosphorous sources. Ceramics International, 37(4): $1219-1229$.

18. Zhao, J., Zhu, Y., Cheng, G., Ruan, Y., Sun, T., Chen, F., Wu, J., Zhao, X. -Y., and Ding, G. (2014). Microwave-assisted hydrothermal rapid synthesis of amorphous calcium phosphate nanoparticles and hydroxyapatite microspheres using cytidine 5'-triphosphate disodium salt as a phosphate source. Materials Letters, 124: 208 - 211.

19. Zhao, J., Dong, X., Bian, M., Zhao, J., Zhang, Y., Sun, Y., Chen, J. and Wang, X. (2014). Solution combustion method for synthesis of nanostructured hydroxyapatite, fluorapatite and chlorapatite. Applied Surface Science, 314: $1026-1033$.

20. Nayak, A. K. (2010). Hydroxyapatite synthesis methodologies: An overview. International Journal of ChemTech Research, 2(2): 903 - 907.

21. Ofomaja, A. E. (2011). Kinetics and pseudo-isotherm studies of 4-nitrophenol adsorption onto mansonia wood sawdust. Industrial Crops and Products, 33(2): $418-428$.

22. Mahamad, M. N., Zaini, M. A. A. and Zakaria, Z. A. (2015). Preparation and characterization of activated carbon from pineapple waste biomass for dye removal. International Biodeterioration \& Biodegradation, 102: $274-280$.

23. Rujitanapanich, S., Kumpapan, P. and Wanjanoi, P. (2014). synthesis of hydroxyapatite from oyster shell via precipitation. Energy Procedia, 56: 112 - 117.

24. Wu, S.-C., Hsu, H.-C., Wu, Y.-N. and Ho, W.-F. (2011). Hydroxyapatite synthesized from oyster shell powders by ball milling and heat treatment. Materials Characterization, 62(12): $1180-1187$.

25. Singh, A. (2012). Hydroxyapatite, a biomaterial: Its chemical synthesis, characterization and study of biocompatibility prepared from shell of garden snail, Helix aspersa. Bulletin of Materials Science, 35(6): 1031 -1038 .

26. Ge, H., Zhao, B., Lai, Y., Hu, X., Zhang, D., and Hu, K. (2010). From crabshell to chitosan-hydroxyapatite composite material via a biomorphic mineralization synthesis method. Journal of Materials Science: Materials in Medicine. 21(6): $1781-1787$.

27. Putro, J. N., Handoyo, N., Kristiani, V., Soenjaya, S. A., Ki, O. L., Soetaredjo, F. E., Ju, Y. -H. and Ismadji, S. (2014). Pomacea sp shell to hydroxyapatite using the ultrasound-microwave method (U-M). Ceramics International, 40(7): $11453-11456$.

28. Spivak, D. A. (2005). Optimization, evaluation, and characterization of molecularly imprinted polymers. Advanced Drug Delivery Reviews, 57(12): 1779 - 1794. 
29. Ariffin, M. M., Yatim, N. I. and Tahir, N. M. (2015). Selective surface characteristics and extraction performance of a nitro-group explosive molecularly imprinted polymer. Malaysian Journal of Analytical Sciences, 19(3): $574-585$.

30. Zhang, X. and Vecchio, K. S. (2007). Hydrothermal synthesis of hydroxyapatite rods. Journal of Crystal Growth, 308(1): $133-140$.

31. Sofronia, A. M., Baies, R., Anghel, E. M., Marinescu, C. A. and Tanasescu, S. (2014). Thermal and structural characterization of synthetic and natural nanocrystalline hydroxyapatite. Materials Science and Engineering $C$, 43: $153-163$.

32. Terasaka, S., Kamitakahara, M., Yokoi, T. and Matsubara, H. (2015). Ability of hydroxyapatite synthesized from waste oyster shells to remove fluoride ions. Materials Transactions, 56(9): 1509 - 1512.

33. Mahidin, M., Gani, A., Muslim, A., Husin, H., Hani, M. R., Syukur, M., Hamdan, Khairil, K. and Rizal, S. (2016). Sulfur removal in bio-briquette combustion using seashell waste adsorbent at low temperature. Journal of Engineering and Technological Sciences, 48(4): 465 - 481.

34. Suteu, D. and Rusu, L. (2012). Removal of methylene blue dye from aqueous solution using seashell wastes as biosorbent. Environmental Engineering and Management Journal, 11(11): 1977 - 1985.

35. Zhang, Y., Liu, W., Banks, C. E., Liu, F., Li, M., Xia, F. and Yang, X. (2014). A fluorescence-quenching platform based on biomineralized hydroxyapatite from natural seashell and applied to cancer cell detection. Scientific Reports, 4: 7556.

36. Zhang, X. and Vecchio, K. S. (2013). Conversion of natural marine skeletons as scaffolds for bone tissue engineering. Frontiers of Materials Science, 7(2): 103 - 117.

37. Narayanan, R., Dutta, S. and Seshadri, S. K. (2006). Hydroxy apatite coatings on Ti-6Al-4V from seashell. Surface and Coatings Technology, 200(16-17): $4720-4730$.

38. Bozbaş, S. K., and Boz, Y. (2016). Low-cost biosorbent: Anadara inaequivalvis shells for removal of $\mathrm{Pb}(\mathrm{II})$ and $\mathrm{Cu}(\mathrm{II})$ from aqueous solution. Process Safety and Environmental Protection, 103: 144 - 152.

39. El-Sayed, G. O., Dessouki, H. A. and Ibrahiem, S. S. (2011). Removal of Zn (II), Cd (II) and Mn (II) from aqueous solutions by adsorption on maize stalks. Malaysian Journal of Analytical Sciences, 15(1): $8-21$.

40. Lee, S. H., and Shrestha, S. (2014). Application of micellar enhanced ultrafiltration (MEUF) process for zinc (II) removal in synthetic wastewater: Kinetics and two-parameter isotherm models. International Biodeterioration and Biodegradation, 95: 241 - 250.

41. Robati, D. (2013). Pseudo-second-order kinetic equations for modeling adsorption systems for removal of lead ions using multi-walled carbon nanotube. Journal of Nanostructure in Chemistry, 3(1): 55 - 61.

42. Largitte, L. and Lodewyckx, P. (2015). Modeling the influence of the operating conditions upon the sorption rate and the yield in the adsorption of lead (II). Microporous and Mesoporous Materials. 202: 147 - 154.

43. Igberase, E., Osifo, P. and Ofomaja, A. (2014). The adsorption of copper (II) ions by polyaniline graft chitosan beads from aqueous solution: Equilibrium, kinetic and desorption studies. Journal of Environmental Chemical Engineering, 2(1): $362-369$.

44. Lim, A. P., and Aris, A. Z. (2014). Continuous fixed-bed column study and adsorption modeling: Removal of cadmium (II) and lead (II) ions in aqueous solution by dead calcareous skeletons. Biochemical Engineering Journal, 87: $50-61$.

45. Mousa, S. M., Ammar, N. S. and Ibrahim, H. A. (2016). Removal of lead ions using hydroxyapatite nanomaterial prepared from phosphogypsum waste. Journal of Saudi Chemical Society, 20(3): 357 -365. 